\title{
Pembuatan Aplikasi Augmented Reality Sebagai Media Pembelajaran Mengenai Tata Surya Berbasis Android Untuk Sekolah Dasar
}

\author{
Labiibah Nur Ainni ${ }^{a}$, Agung Budi Prasetyo, M.T ${ }^{b}$ \\ ${ }^{a}$ Politeknik Negeri Media Kreatif Jakarta, Jl. Srengseng Sawah, Jagakarsa Jakarta Selatan 12640 \\ ${ }^{b}$ Politeknik Negeri Media Kreatif Jakarta, Jl. Srengseng Sawah, Jagakarsa Jakarta Selatan 12640
}

\section{INFORMASI ARTIKEL}

\section{Sejarah Artikel:}

Diterima Redaksi: 4 September 2020

Revisi Akhir: 2 Desember 2020

Diterbitkan 15 Desember 2020

\section{KATA KUNCI}

Tata Surya

Augmented Reality

Aplikasi Android

\section{KORESPONDENSI}

Email a : labiibahnurainni@gmail.com

E-mail b: agung@polimedia.ac.id

\section{A B S T R A C T}

Sistem Tata Surya terdapat pada pelajaran IPA (Ilmu Pengetahuan Alam) yang merupakan materi yang wajib dikuasai oleh siswa Sekolah Dasar. Pada materi pembelajaran ini siswa diajak untuk mengenal planet-planet dengan membayangkan seperti apa keadaan di dalam sistem Tata Surya. Tujuan dari pembuatan Karya Tugas Akhir ini yaitu membangun sebuah aplikasi Augmented reality sebagai media pembelajaran tambahan yang dapat digunakan sebagai alternatif penyampaian informasi mengenai materi Tata Surya di Sekolah Dasar. Pada jurnal sebelumnya telah dibuat aplikasi pembelajaran materi Tata Surya menggunakan teknologi AR yang membahas materi planet Tata Surya, dan pada penelitian ini akan dikembangkan dengan membuat media pembelajaran IPA materi Tata Surya menggunakan Teknologi Augmented reality (AR) berbasis Android yang mengakomodasi seluruh bahasan materi Tata Surya yang terdapat pada buku SD/MI kelas 6 untuk Sekolah Dasar. Materi penjelasan yang ada pada buku akan didigitalisasikan ke dalam bentuk aplikasi berbasis Augmented reality berupa objek 3d. Marker yang digunakan adalah buku SD/MI kelas 6 untuk Sekolah Dasar. Aplikasi Augmented reality ini dirancang dan dibuat untuk Android version. Aplikasi ini optimal digunakan pada Android dengan Operating System Android Versi Nougat hingga Pie.

DOI: https://doi.org/10.25077/xxxxx (10 pt)

\section{PENDAHULUAN}

Tata surya merupakan suatu sistem yang terdiri dari Matahari sebagai pusat tata surya yang dikelilingi oleh semua objek yang terikat oleh gravitasinya [1]. Pembelajaran sistem Tata Surya terdapat pada pelajaran IPA (Ilmu Pengetahuan Alam) yang merupakan materi yang wajib diketahui oleh siswa Sekolah Dasar, berdasarkan Kompetensi Inti Mata Pelajaran IPA untuk SD/MI Kelas VI Kurikulum 2013, bahwa pengajar harus mampu menjelaskan sistem Tata Surya dan karakteristik anggota Tata Surya[2]. Pada materi pembelajaran ini siswa diajak untuk mengenal planet-planet dengan membayangkan seperti apa keadaan di dalam sistem Tata Surya. Dalam proses pembelajaran pemakaian media sangat penting karena dapat membangkitkan keinginan dan minat, membangkitkan motivasi dan rangsangan terutama membantu siswa untuk belajar[3]. Mengutip dari jurnal bahwa media pembelajaran materi Tata Surya saat ini masih sangatlah minim, serta kurangnya respon murid karena guru kesulitan dalam memaparkan materi Tata Surya [4].

Kemajuan teknologi multimedia khususnya multimedia pembelajaran dapat membantu meningkatkan minat belajar karena semuanya yang serba digital, salah satunya adalah dengan memanfaatkan perangkat handphone [5]. Perpaduan dunia teknologi dan pendidikan mampu memberikan manfaat pada proses pembelajaran karena memiliki potensi yang sangat 
besar untuk perkembangan pengajaran, seperti melalui teknologi AR (Augmented Reality). Pemanfaatan teknologi AR (Augmented Reality) dalam pembelajaran memiliki kelebihan salah satunya yaitu dapat melatih kreatifitas dan imajinasi peserta didik[6].

Penelitian terkait penggunaan aplikasi AR (Augmented Reality) menunjukan bahwa media pembelajaran IPA menggunakan AR (Augmented Reality) berbasis Android mendapatkan respon sangat baik dengan persentase rata-rata sebesar 93,3\%[7]. Menurut penelitian Ismi Naili Qurrotul Aini, Agung Triayudi dan Ira Diana Sholihati (2020) yang telah membuat aplikasi AR (Augmented Reality) untuk media pembelajaran Tata Surya di Sekolah Dasar menunjukkan bahwa aplikasi Augmented Reality mengenai materi sistem Tata Surya dapat digunakan sebagai media pembelajaran untuk siswa Sekolah Dasar sehingga belajar lebih menyenangkan. Aplikasi yang sudah dibuat sebelumnya hanya terbatas pada materi Tata Surya yaitu Matahari, Merkurius, Venus, Bumi, Mars, Yupiter, Saturnus, Uranus, Neptunus, Uranus, Bulan dan Asteroid. Sehingga, masih menyisakan materi benda angkasa lain yaitu Komet dan Meteoroid pada Tata Surya jika dilihat pada materi Tata Surya untuk siswa Sekolah Dasar. Metode yang digunakan sebelumnya yaitu Marker Based tracking dengan media Marker booklet berupa gambar pola hitam putih yang harus di download melalui google drive. Penambahan bahasan materi pengenalan Tata Surya pada buku Sekolah Dasar Pelajaran IPA Kelas 6 diharapkan mampu untuk meningkatkan minat dan dapat dengan mudah memahami tentang pembelajaran Tata Surya.

\section{TINJAUAN PUSTAKA}

\subsection{Media Pembelajaran}

Dalam bahasa Arab, media adalah perantara atau pengantar pesan dari pengirim kepada penerima pesan. Menurut Gerlach dan Ely dalam Arsyad (2014, hlm. 3) mengatakan bahwa media apabila dipahami secara garis besar adalah manusia, materi atau kejadian yang membangun kondisi yang membuat siswa mampu memperoleh pengetahuan, keterampilan, atau sikap[8]. Dalam pengertian ini guru, buku teks dan lingkungan sekolah merupakan media. Secara lebih khusus, pengertian media dalam proses belajar mengajar cenderung diartikan sebagai alat-alat grafis, photografis atau elektronis untuk menangkap, memproses dan menyusun kembali informasi visual atau verbal.

Menurut Association for Education and Communication technologi (AECT) media pada Sadiman dkk (1996, hlm. 6) adalah segala bentuk yang dipergunakan untuk suatu proses penyaluran informasi. Sedangkan Education Association (NEA) menyatakan bahwa media sebagai benda yang dapat dimanipulasikan, dilihat, didengar, dibaca atau dibicarakan beserta yang dipergunakan dengan baik dalam kegiatan belajar mengajar, instrumen dapat mempengaruhi efektifitas program instruksional[9]. Di dalam proses belajar mengajar yang pada hakikatnya juga merupakan proses penyampaian pesan atau proses komunikasi, informasi atau pesan yang dikomunikasikan adalah isi atau bahan ajar yang telah ditetapkan dalam kurikulum. Dalam proses komunikasi, biasanya guru berperan sebagai komunikator yang bertugas menyampaikan bahan ajar (pesannya) kepada siswa (penerima pesan).

Dari definisi di atas dapat ditarik kesimpulan bahwa media pembelajaran adalah suatu cara, alat, atau proses yang digunakan untuk menyampaikan pesan dari sumber pesan kepada penerima pesan yang berlangsung dalam proses pendidikan. Penggunaan media dalam pembelajaran dalam proses belajar mengajar dapat membangkitkan keinginan dan minat yang baru, membangkitkan motivasi dan rangsangan kegiatan belajar, bahkan membawa pengaruh psikologis terhadap siswa.

\subsection{Augmented Reality}

Menurut Andre Kurniawan P., Maryuni dan Ridwan S. definisi Augmented Reality atau yang sering disingkat dengan AR ini berbeda dengan Virtual Reality yang kerap disebut VR. Augmented reality tidaklah seperti Virtual Reality yang sepenuhnya menggantikan kenyataan, Augmented Reality hanya sekedar melengkapi atau menambahkan kenyataan. Hal ini membuat Augmented reality sesuai sebagai alat untuk membantu persepsi dan interaksi penggunanya dengan dunia nyata. Informasi yang ditampilkan oleh benda maya membantu pengguna melaksanakan kegiatan-kegiatan dalam dunia nyata[10].

Augmented reality dapat diaplikasikan untuk semua indera, termasuk pendengaran, sentuhan, dan penciuman. Selain digunakan dalam bidang-bidang seperti kesehatan, militer, industri manufaktur, Augmented reality juga telah diaplikasikan dalam perangkat-perangkat yang digunakan orang banyak, seperti pada telepon genggam.

Sedangkan menurut definisi yang diberikan oleh Ronald T. Azuma (1997) mendefinisikan Augmented reality sebagai penggabungan benda-benda nyata dan maya di lingkungan nyata, berjalan secara interaktif dalam waktu nyata (realtime), dan terdapat integrasi antar benda dalam tiga dimensi, yaitu benda maya terintegrasi dalam dunia nyata[11]. Penggabungan benda nyata dan maya dimungkinkan dengan teknologi tampilan yang sesuai interaktivitas dimungkinkan melalui perangkatperangkat input tertentu. Bidang-bidang yang menerapkan teknologi Augmented reality adalah:

1. Bidang pemasaran digunakan untuk mempromosikan barang atau jasa dengan brosur virtual yang memberikan informasi lengkap secara tiga dimensi sehingga pelanggan dapat mengetahui secara jelas mengenai barang atau jasa yang ditawarkan.

2. Bidang pendidikan digunakan untuk proses belajar mengajar yang memberikan efek-efek yang dapat mengubah gambar animasi tentang cuaca tersebut.

3. Bidang desain teknologi digunakan untuk menampilkan hasil desain mereka secara nyata terhadap klien.

\subsubsection{Metode Penggunaan Augmented reality}

Secara garis besar, Augmented reality ini terbagi menjadi 2 metode, yakni Marker Based tracking dan juga markerless Augmented reality. Berikut ini adalah metode yang digunakan atau dikembangan pada teknologi Augmented reality (AR) ini:

\section{Metode Marker Based Tracking}

Biasanya metode ini menggunakan ilustrasi yang berwarna hitam dan juga putih dengan bentuk persegi, dan terdapat batasan hitam tebal berlatar belakang putih. Pada metode 
Marker Based tracking akan digunakan tiga sumbu utama yakni $\mathrm{X}, \mathrm{Y}$, dan $\mathrm{Z}$ dengan bantuan titik koordinat $(0,0,0)$ dan juga virtual secara 3 dimensi. Metode jenis ini mulai dikembangan dari tahun 1980 an, namun secara khusus dikenal oleh masyarakat sekitar awal tahun 1990-an.

2. Markerless Augmented reality

Untuk metode yang satu ini yang bernama Markerless Augmented reality pada saat ini sedang giat dikembangkan. Keuntungan dari metode jenis ini adalah pengguna tidak lagi memerlukan peralatan tambahan hanya untuk menampilkan berbagai macam elemen digital.

\subsubsection{Prinsip Kerja Augmented reality}

Prinsip kerjanya sederhana yaitu kamera yang telah dikalibrasikan akan mendeteksi Marker yang diberikan, kemudia mengenali dan menandai pola Marker, kamera akan melakukan perhitungan apakah Marker sesuai dengan database yang dimiliki. Bila tidak maka informasi Marker tidak akan diolah, tetapi bila sesuai maka informasi Marker akan d gunakan untuk me-render dan menampilkan objek tiga dimensi yang telah di buat sebelumnya.

\subsection{Tata Surya}

Nunik Nurhidayati, Efrie L., Nanang Rusmana \& Jumali (2013), menjelaskan bahwa Tata Surya adalah kumpulan benda langit yang berputar mengelilingi Matahari. Benda - benda langit itu adalah bulan, asteroid, meteoroid, komet, dan planet - planet. Tata Surya memiliki berbagai benda benda langit diantaranya matahari [12].

Matahari merupakan pusat Tata Surya yang berupa bola gas yang bercahaya. Matahari merupakan salah satu bintang yang menghiasi galaksi Bima Sakti. Suhu permukaan matahari 6.000 derajat Celsius yang dipancarkan ke luar angkasa hingga sampai ke permukaan bumi, sedangkan suhu inti sebesar 15-20 juta derajat Celsius. Planet yang terdekat terhadap matahari mempunyai skala revolusi terkecil. Planet-planet penyusun Tata Surya antara lain: Merkurius, Venus, Bumi, Mars, Yupiter, Saturnus, Uranus, Neptunus. Dalam susunan tata surya kita, selain planet-planet, ada benda-benda langit lainnya, yaitu asteroid, komet, meteoroid, dan satelit.

\section{4. $U M L$}

Menurut Windu Gata, Grace (2013:4), Unified Modeling Language (UML) adalah bahasa spesifikasi standar yang dipergunakan untuk mendokumentasikan, menspesifikasikan dan membanngun perangkat lunak. UML merupakan metodologi dalam mengembangkan sistem berorientasi objek dan juga merupakan alat untuk mendukung pengembangan sistem[13]. Alat bantu yang digunakan dalam perancangan berorientasi objek berbasiskan UML adalah sebagai berikut:

\subsubsection{Use Case Diagram}

Use Case Diagram merupakan pemodelan untuk kelakuan (behavior) sistem informasi yang akan dibuat. Use Case digunakan untuk mengetahui fungsi apa saja yang ada di dalam sistem informasi dan siapa saja yang berhak menggunakan fungsi-fungsi tersebut. Simbol-simbol yang digunakan dalam Use Case Diagram yaitu:

\subsubsection{Activity Diagram}

Activity Diagram menggambarkan workflow (aliran kerja) atau aktivitas dari sebuah sistem atau proses bisnis.

\subsubsection{Sequence Diagram}

Sequence Diagram menggambarkan kelakuan objek pada Use Case dengan mendeskripsikan waktu hidup objek dan pesan yang dikirimkan dan diterima antar objek.

\subsubsection{Class Diagram}

Merupakan hubungan antar kelas dan penjelasan detail tiap-tiap kelas di dalam model desain dari suatu sistem, juga memperlihatkan aturan-aturan dan tanggung jawab entitas yang menentukan perilaku sistem. Class Diagram juga menunjukkan atribut-atribut dan operasi-operasi dari sebuah kelas dan constraint yang berhubungan dengan objek yang dikoneksikan. Class Diagram secara khas meliputi : Kelas (Class), Relasi Associations, Generalization dan Aggregation, attribut (Attributes), operasi (operation/method) dan visibility, tingkat akses objek eksternal kepada suatu operasi atau atribut. Hubungan antar kelas mempunyai keterangan yang disebut dengan Multiplicity atau Cardinality.

\section{KONSEP PERANCANGAN}

Penulis mengembangkan media pembelajaran mengenai materi Tata Surya yaitu menggunakan teknologi Augmented Reality yang mengakomodasi seluruh bahasan materi Tata Surya yang terdapat pada buku SD/MI kelas 6 untuk Sekolah Dasar. Aplikasi ini menampilkan objek 3D dengan tambahan informasi mengenai objek tersebut dengan metode Marker Based tracking yang akan diterapkan pada buku IPA Kelas 6 SD/MI sebagai objek Markernya. Untuk dapat mengakses aplikasi Augmented Reality ini user harus mengunduh terlebih dahulu aplikasinya dan menyiapkan buku IPA Kelas 6 SD/MI sebagai media Marker untuk menjalakan aplikasi yang penulis buat. Dimulai dari pengambilan kebutuhan, kemudian dilanjutkan dengan analisis, perancangan, implementasi dan terakhir pengujian sistem. Analisis dan perancangan dengan menggunakan simbolsimbol diagram UML. Hal ini ditujukan untuk standarisasi dan kemudahan, serta diharapkan dapat berfungsi dengan baik.

\subsection{Use Case Diagram}

Use Case Diagram menyatakan visualisasi interaksi yang terjadi antara pengguna (aktor) dengan sistem. Diagram ini bisa 
menjadi gambaran yang bagus untuk menjelaskan konteks dari sebuah sistem sehingga terlihat jelas batasan dari sistem (Larman, 2005). Berikut ini adalah Use Case Diagram dari aplikasi Sistem Tata Surya berbasis Augmented reality yang telah penulis buat:

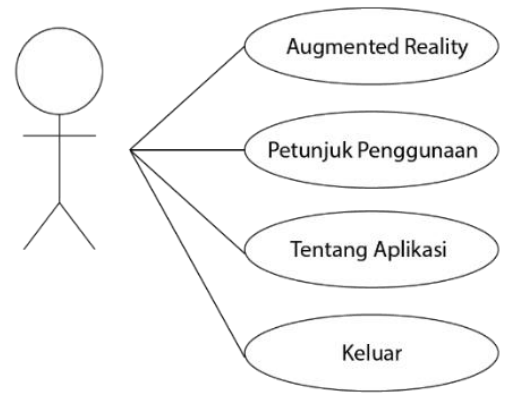

Gambar 3.1 Use Case Diagram

\subsection{Activity Diagram}

Activity Diagram menunjukkan aktivitas sistem dalam bentuk kumpulan aksi-aksi, bagaimana masing-masing aksi tersebut dimulai, keputusan yang mungkin terjadi hingga berakhirnya aksi. Activity Diagram juga dapat menggambarkan proses lebih dari satu aksi salam 17 waktu bersamaan. "Diagram activity adalah aktifitas-aktifitas, objek, state, transisi state dan event. Dengan kata lain kegiatan diagram alur kerja menggambarkan perilaku sistem untuk aktivitas" (Haviluddin, 2011).

\section{Activity Diagram Main Menu}

Activity Diagram main menu ini menggambarkan kejadian dimana user dapat menjalankan aplikasi, mulai dari membuka aplikasi dan menampilkan menu utama kemudian keluar dari aplikasi.

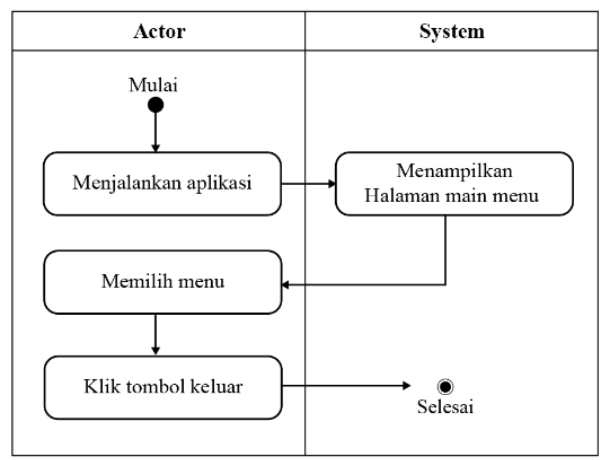

Gambar 3.2 Activity Diagram Main Menu

\section{Activity Diagram Augmented reality Camera}

Activity Diagram ini menggambarkan aktivitas ketika aktor menekan tombol AR Camera, kemudian sistem akan mengaktifkan halaman AR Camera.

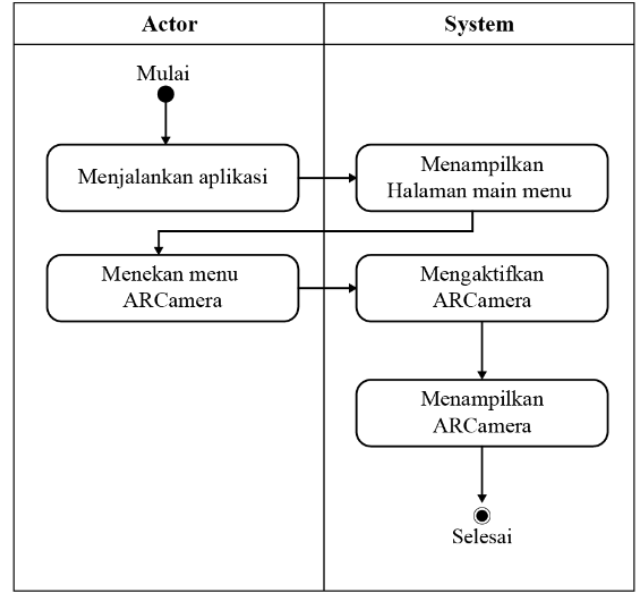

Gambar 3.3 Activity Diagram AR Camera

\section{Activity Diagram Marker Scanning}

Activity Diagram ini menggambarkan aktivitas ketika aktor memindai Marker dengan Augmented reality, kemudian Marker akan terdeteksi hingga muncul objek 3D.

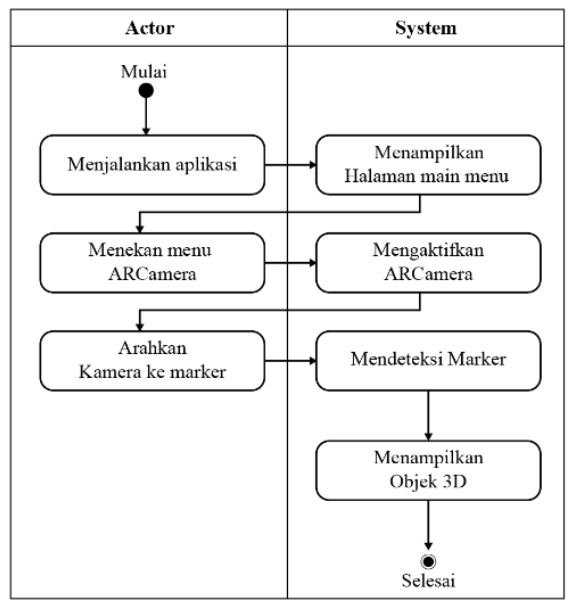

Gambar 3.4 Activity Diagram Marker Scanning

\section{Activity Diagram Petunjuk Penggunaan}

Activity Diagram petunjuk penggunaan ini menggambarkan kejadian dimana user saat memilih tombol petunjuk penggunaan, lalu sistem akan menampilkan petunjuk penggunaan untuk dapat menggunakan teknologi Augmented reality pada aplikasi. 


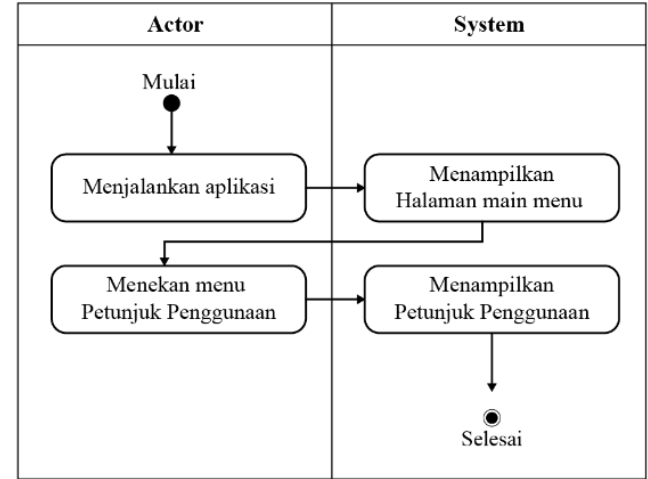

Gambar 3.5 Activity Diagram Petunjuk Penggunaan

\section{Activity Diagram Tentang Aplikasi}

Activity Diagram tentang aplikasi ini menggambarkan kejadian dimana user saat memilih tombol tentang aplikasi, lalu sistem akan menampilkan informasi dan hak cipta dari aplikasi.

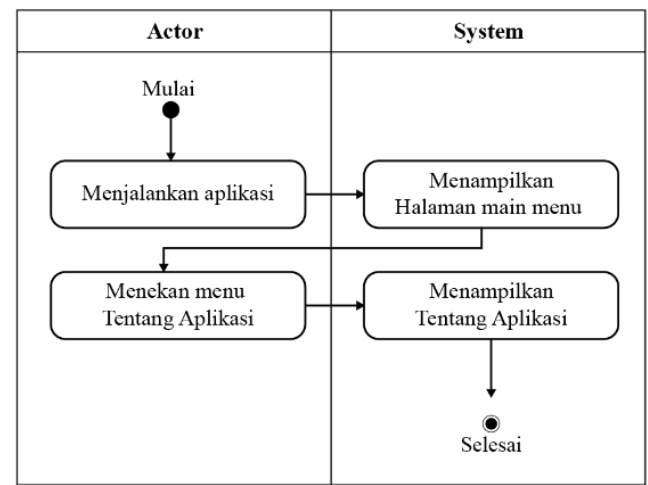

Gambar 3.6 Activity Diagram Tentang Aplikasi

\subsection{Class Diagram}

Class Diagram mendiskripsikan jenis-jenis objek dalam sistem dan berbagai macam hubungan statis yang terjadi. Selain itu, Class Diagram juga menunjukan properti dan operasi sebuah class dan batasan yang terdapat dalam hubunggan dengan objek. Class Diagram merupakan alat yang tergolong baik dalam perancangan perangkat lunak. Class Diagram dapat membantu pengembang mendapatkan struktur sistem dan menghasilkan rancangan sistem yang baik. Berikut dari Class Diagram aplikasi Tata Surya berbasis Augmented reality yang telah penulis buat.

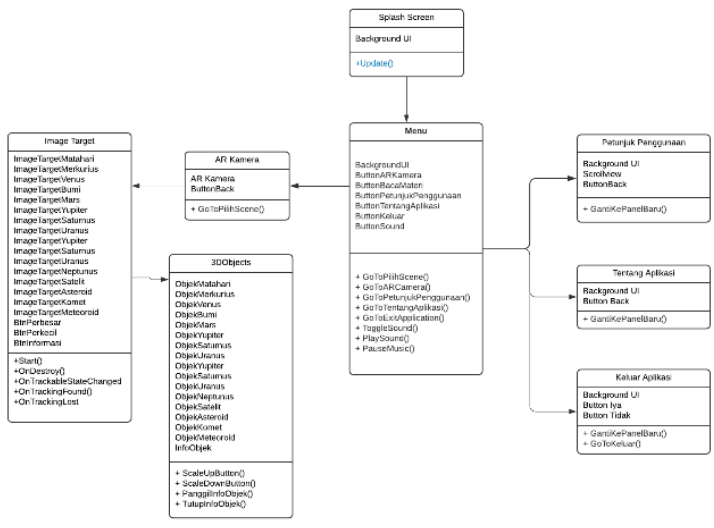

Gambar 3.7 Class Diagram Aplikasi AR Tata Surya

\section{HASIL DAN PEMBAHASAN}

Dibawah ini merupakan hasil visualisasi dari implementasi User Interface yang telah dibentuk dari sebuah kerangka, sehingga menjadi bentuk karya siap pakai pada aplikasi yang akan dibuat.

\subsection{Implementasi User Interface}

\subsubsection{Tampilan Halaman Splash Screen}

Berikut hasil impelentasi halaman splash screen dari sebuah rancangan yang dibuat sebelumnya:

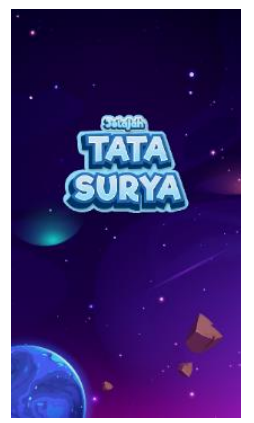

Gambar 4.1 Tampilan Splash Screen

\subsubsection{Tampilan Halaman Splash Screen}

Halaman menu utama adalah tampilan yang berisi lima pilihan menu untuk memasuki halaman lainnya. 


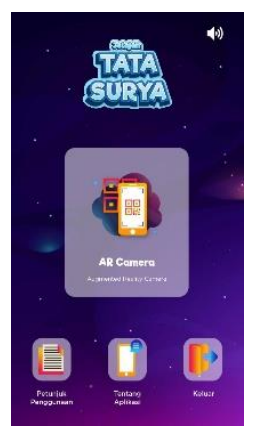

Gambar 4.2 Tampilan Menu Utama

\subsubsection{Tampilan Halaman AR Camera}

Berikut hasil impelentasi halaman AR Camera dari sebuah rancangan yang dibuat sebelumnya:

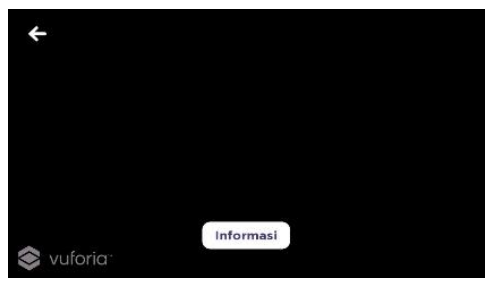

Gambar 4.3 Tampilan AR Camera

\subsubsection{Tampilan Halaman Petunjuk Penggunaan}

Halaman petunjuk penggunaan merupakan tampilan petunjuk penggunaan dalam menggunakan fitur Augmented reality:
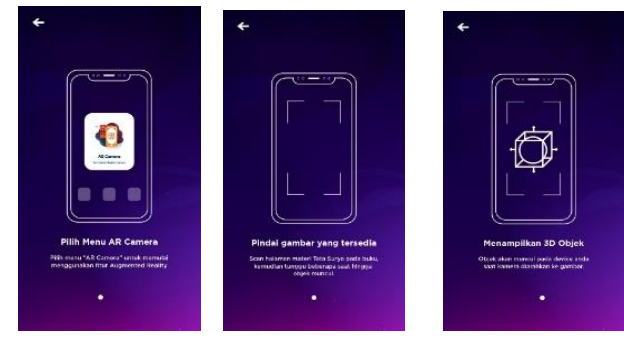

Gambar 4.4 Tampilan Petunjuk Penggunaan

\subsubsection{Tampilan Halaman Tentang Aplikasi}

Halaman tentang aplikasi menampilkan informasi aplikasi dan pembuat dalam aplikasi ini.

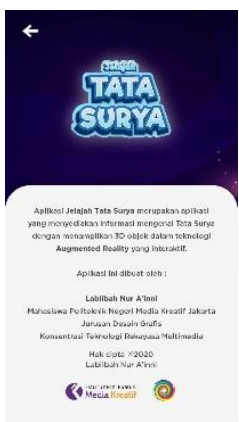

Gambar 4.5 Tampilan Tentang Aplikasi

\subsubsection{Tampilan Halaman Keluar}

Berikut hasil impelentasi halaman keluar dari sebuah rancangan yang dibuat sebelumnya:

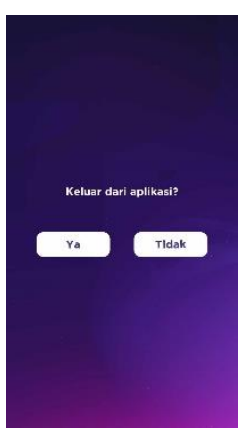

Gambar 4.6 Tampilan Keluar Aplikasi

\subsection{Pengujian Sistem}

Berdasarkan hasil pengujian aplikasi yang dilakukan pada empat perangkat dan melakukan pengujian berdasarkan jarak, cahaya ruangan dan sudut maka dapat disimpulkan:

1. Aplikasi dapat diberjalan pada semua perangkat, mulai dari OS Android versi Nougat higga versi Pie.

2. Pada Tabel 4.6 hasil uji coba aplikasi berdasarkan jarak, bahwa marker tidak terbaca pada jarak $5 \mathrm{~cm}$, terbaca lambat pada jarak $30 \mathrm{~cm}$, dan terbaca dengan baik pada jarak antara $15 \mathrm{~cm}$ sampai $25 \mathrm{~cm}$.

3. Pada Tabel 4.7 hasil uji coba aplikasi berdasarkan sudut, bahwa marker tidak akan terbaca pada sudut $90^{\circ}$, dan terbaca dengan baik pada sudut antara $0^{\circ}$ sampai $45^{\circ}$.

\section{KESIMPULAN DAN SARAN}

\subsection{Kesimpulan}

Pada pembuatan pembuatan aplikasi Augmented reality mengenai Tata Surya untuk Sekolah Dasar berbasis Android, terdapat beberapa kesimpulan yang penulis dapat. Berikut kesimpulan dari pembuatan Karya Tugas Akhir ini:

- Aplikasi Augmented reality mengenai Tata Surya untuk Sekolah Dasar berbasis Android adalah sebagai media pembelajaran tambahan yang dapat dipakai dengan 
tambahan detail berupa objek 3D yang bersangkutan langsung dengan objek, untuk materi Tata Surya pada buku IPA SD/MI Kelas 6.

- Pengenalan Marker terbaik saat melakukan pemindaian terdapat pada jarak $15 \mathrm{~cm}$ sampai $25 \mathrm{~cm}$ dan dapat terbaca sudut $0^{\circ}$ sampai $45^{\circ}$.

Aplikasi Augmented reality mengenai mengenai Tata Surya untuk Sekolah Dasar berbasis Android d ini dapat dipakai di minimal di Operating System Android v6.0(Marshmallow) - v9.0( Pie) dan RAM minimal 3Gb.

\subsection{Saran}

Beberapa hal yang dapat dikembangkan dari aplikasi Aplikasi Augmented reality mengenai Tata Surya untuk Sekolah Dasar berbasis Android ini diantaranya adalah:

- Sistem operasi yang dikembangkan selain Android, dapat juga dikembangkan di iOS.

- Dapat dipublikasikan secara umum, seperti di Google Play Store.

\section{DAFTAR PUSTAKA}

[1] Dwi Suhartanti, Isnaini A.Z., Yulinda E.S., "Ilmu Pengetahuan Alam Untuk Kelas VI SD/MI," Jakarta: Departemen Pendidikan Nasional, 2008, 112.

[2] Permendikbud Nomor 37 Tahun 2018 Tentang Kompetensi Inti dan Kompetensi Dasar Kurikulum 2013 Ilmu Pengetahuan Alam SD/MI.

[3] Arsyad, A. (2014). "Media Pembelajaran (Edisi Revisi)," Jakarta: Rajawali Press.

[4] Tresnawati, D., \& Nugraha, A. P. (2017). "Rancang Bangun Game Edukasi Sistem Tata Surya," Jurnal STTGarut, 14., 1, , 360-370.

[5] Riva Atun Islamiyati, "Pemanfaatan Handphone dalam Proses Pembelajaran Ekonomi Di SMA A dan SMA B Jakarta Selatan," (Jakarta: Universitas Islam Negeri Syarif Hidayatullah). hlm 4.

[6] Yuen, S. C., Yaoyuneyong, G. dan Johnson, "E. Augmented reality: An Overview and Five Directions for AR in Education." Journal of Educational Technology Development and Exchange. 4: 119-140, 2011.

[7] Fitriani Eka S., Muhsinah Annisa dan Dedi Kusnandi, "Pengembangan Media Pembelajaran IPA Menggunakan Augmented reality (A) Berbasis Android Pada Siswa Kelas III SDN 015 Tarakan," S.Pd Tugas Akhir (Kalimantan: Universitas Borneo Tarakan), hal 60.

[8] Arsyad, A. (2014). "Media Pembelajaran (Edisi Revisi)," Jakarta: Rajawali Press.

[9] Sadiman, A.S., Rahardjo, R., Haryono, A., \& Rahardjito. (2010). "Media Pendidikan: Pengertian, Pengembangan, dan Pemanfaatannya," Jakarta: Pustektom Dikbud \& PT. Raja Grafindo Persada.
[10] Pamoedji, Andre Kurniawan, Maryuni, Ridwan Sanjaya, (2017). "Buku Mudah Membuat Game Augmented Reality (AR) dan Virtual Reality (VR) dengan Unity 3D," Jakarta: Elex Media Komputindo.

[11] Azuma, R. T. (1997). "A Survey of Augmented reality," Teleoperatorts and Virtual Enviroments. 6: 355-385

[12] Nunik Nurhidayati, Efrie L., Nanang Rusmana \& Jumali, "Ilmu Pengetahuan Alam Untuk Kelas VI SD/MI," Jakarta : Penerbit Duta, 2013, 134.

[13] Gata, Windu dan Gata, Grace. (2013). "Sukses Membangun Aplikasi Penjualan dengan Java," Jakarta : Elex Media Komputindo.

\section{BIODATA PENULIS}

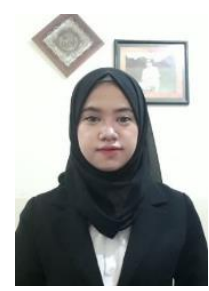

\section{Labiibah Nur Ainni}

Lahir di Jakarta pada tanggal 17 Juni 1998, merupakan mahasiswa tingkat akhir Jurusan Desain Grafis Konsentrasi Multimedia di Politeknik Negeri Media Kreatif Jakarta.

Semasa kuliah, Labiibah telah berperan aktif mengikuti lomba nasional mewakili kampus diantaranya GEMASTIK XII bidang Pengembangan Aplikasi Permainan (Games Development) yang diadakan oleh Telkom University dan KBMI (Kompetisi Bisnis Mahasiswa Indonesia) 2019 Industri Kreatif dengan bisnis Jacket Jeans Painting yang dibangun bersama temannya bernama "Youngkru.id" dan juga ia aktif di berbagai kegiatan kepanitiaan acara kampus sebagai public relations diantaranya yaitu AMUBA 5 (Aksi Multimedia Berbagi), HEST (Himedia E-Sport Tournament) \& MAX 5 (Media Art Exhibition).

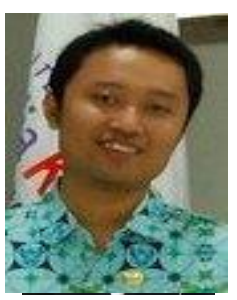

Agung Budi Prasetyo, MT

Merupakan kepala program studi Sarjana Terapan Teknologi Rekayasa Multimedia di Politeknik Negeri Media Kreatif. 
